\title{
HIGH AND VERY HIGH AVALANCHE RISK DURING 2016-2017 WINTER SEASON
}

\author{
N. MILIAN $N^{I}$, U. RECKERTH ${ }^{2}$
}

\begin{abstract}
High and very high avalanche risk during 2016-2017 winter season. The paper presents and analyze snow and meteorological conditions of 2016-2017 winter, which led to the estimation of high and very high avalanche risk in Bucegi and Făgăraş Mountains, the two areas covered by nivological program of the Romanian National Meteorological Administration. Meteorological and specific snow parameters measured everyday at the four meteorological stations within the nivologic program (Sinaia, Predeal, Vârfu Omu and Bâlea-Lac) have been studied, along with the estimated avalanche risk and the avalanche events that took place during the studied periods.
\end{abstract}

Keywords: avalanches, snow, risk, Bucegi and Făgăraş Mountains

\section{INTRODUCTION}

At National Meteorological Administration, daily bulletins that include avalanche risk estimations are issued since January 2005. It is the only institution in Romania that issues avalanche risk estimation, according to the European Avalanche Danger Scale. Annual reports include studies about the evolution of avalanche risk during winters $(* * *, 2011-2017)$. The study aims to present and analyze snow and meteorological parameters evolution during 2016-2017 winter, which led to the estimation of high and very high avalanche risk in the monitored area of Bucegi and northern Făgăraş Mountains, representing a potential threat to skiers and tourists, because in these cases the snowpack is unstable and poorly bonded on most steep slopes and natural, spontaneous, avalanches can be expected. Because of the variety of conditions that can lead to instability of snow, every risk situations should be studied, in order to create a pattern of avalanche danger (Green et al. 2006) and improve avalanche risk forecasting.

\section{SNOW EVOLUTION DURING 2016-2017 WINTER}

Based on meteorological and snow parameters measured at four weather stations within the snow and avalanche program (Vârfu Omu, Sinaia, Predeal and Bâlea-Lac), the avalanche risk is estimated for Bucegi and Făgăraş Mountains. The methodology consists in identifying the periods with recorded avalanches and analyzing the meteorological parameters which could have influenced the stability

\footnotetext{
${ }^{1}$ Doctoral School of Sciences, Craiova University, Romania, email: narcisa.milian@gmail.com

${ }^{2}$ Regional Meteorological Center Transilvania Sud, Sibiu, 49 Someşului str, 550003 Sibiu, Romania, email: udo.reckerth@gmail.com
} 
of the snow pack. Some influences are obvious, like, for example, heating, which determines the humidification of the snow layer and release of wet avalanches, or important snowfalls. The primary data set used in this study consists of daily observed avalanche data and weather data (Castebrunet $\mathrm{H}, 2012$ ) from the massifs where operational avalanche forecasting is done (Bucegi and Făgăraş). Avalanche observations are also taken from local mountain rescue teams. The majority of these avalanche observations can be accessed online in the Annual Report (***, Bilanţul nivologic). Hourly observations and daily precipitation data from the meteorological weather stations of Bucegi and Făgăraş Mountains were used to characterize local weather (***, Baza de date).

Snow layer was continuous at all four stations from 2016, November 29 to 2017, February 5. The maximum snow thickness was measured at Bâlea-Lac on 25 April 2017 and had the value of $231 \mathrm{~cm}$. At the other stations, the highest values were: $114 \mathrm{~cm}$ at Omu Peak (21 April 2017), $72 \mathrm{~cm}$ at Predeal (January 12, 2017) and $27 \mathrm{~cm}$ at Sinaia (30 December 2016) (Fig.1). Snow height was over $200 \mathrm{~cm}$ for just 6 consecutive days (22-27 April 2017) at Bâlea-Lac (Fig.1).

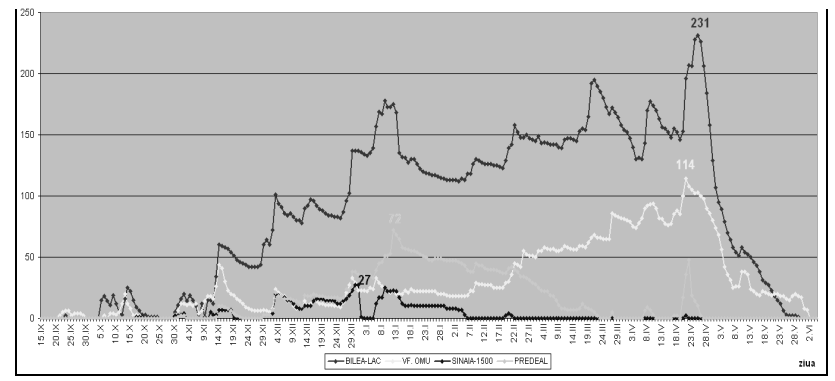

Fig.1. Snow thickness variations at weather stations Bâlea-Lac, Vârfu Omu, Sinaia and Predeal, during 2016-2017 winter

\section{AVALANCHE RISK ESTIMATION}

Estimating the avalanche risk at one mountain massif scale is made in accordance with the European avalanche risk scale. Maximum estimated avalanche risk for one day is considered the highest between all monitored mountains. For this season, the maximum avalanche risk estimated coincided with the estimated risk values for the northern part of the Făgăraş Mountains at altitudes over $1800 \mathrm{~m}$. In percentage, the most commonly avalanche risk used was considerable-3(38.0\%), moderate-2 (35.4\%), high-4 (14.1\%), low-1 (3.6\%) and very high-5 (1.0\%) (fig.2).

Comparing the estimated avalanche risk for Bucegi and Făgăraş Mountains at altitudes higher than 1800 meters, it is observed that the very high risk (5) was used only for Făgăraş, where the percentage use of high risk (4) was also greater than in Bucegi. For Făgăraş Mountains, at altitudes above 1800 meters, the estimated avalanche risk was very high (5) in 22 and 23 April 2017 and high (4) between 30 December 2016 and 3 January 2017, from 7 to 16th of January 2017, 21 and 22 March 2017, 9 to 11 and 21, 24 to 29 April 2017. 


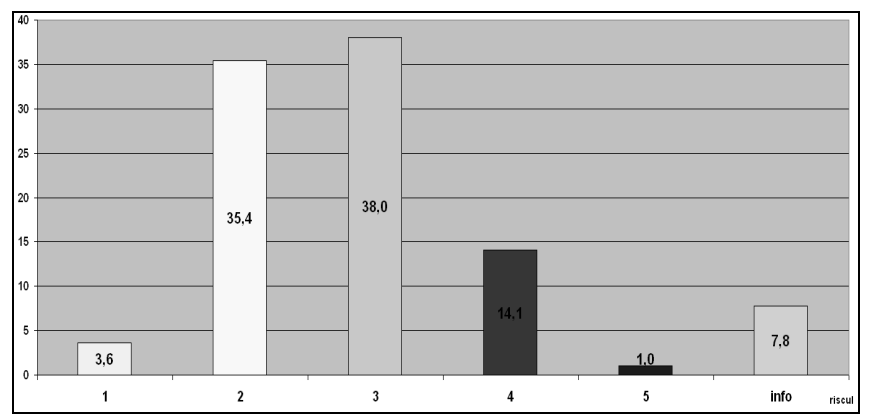

Fig.2. Maximum avalanche risk estimated during 2016-2017 winter

For Bucegi Mountains, at altitudes above 1800 meters, the estimated avalanche risk was high (4) between 30 December 2016 and 3 January 2017, from 7 to 14th of January 2017 and between 21 and 29 April 2017 (fig.3).

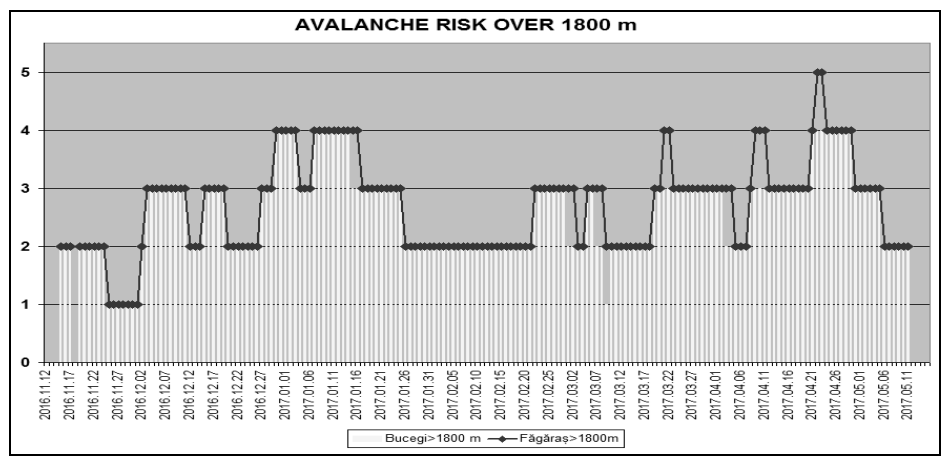

Fig.3. Avalanche risk estimated in Bucegi and Făgăraş Mountains, at altitudes higher than 1800m, during 2016-2017 winter season

\section{PERIODS WITH HIGH AND VERY HIGH AVALANCHE RISK}

\subsection{Meteorological and snow conditions from 2016.12.30 - 2017.01.03}

Abundant snow has fallen since December 27/28, 2016, so that the snow layer has increased from $96 \mathrm{~cm}$ (on the afternoon of December 27) to $137 \mathrm{~cm}$ (on the morning of December 29) - wich means $41 \mathrm{~cm}$ of fresh snow, powder like, with small cohesion between snow crystals, on the meteorological platform. In the valleys, great snow accumulations have been formed. Temperature values were quite low: -11.1 degrees on December 28, -14.9 on the night of December 28/29 and -11.1 degrees on the night of December 27/28. That large amount of noncohesive snow increased the risk of spontaneous avalanche triggering on most inclined slopes, so that the estimated avalanche risk for this period was high (4) (Fig.4). Next four days, the weather continued to be very cold, with maximum 
temperatures of -14.3 degrees on December 29 and minus -17.0 degrees on December 29/30 and -17.3 degrees on December 30/31.
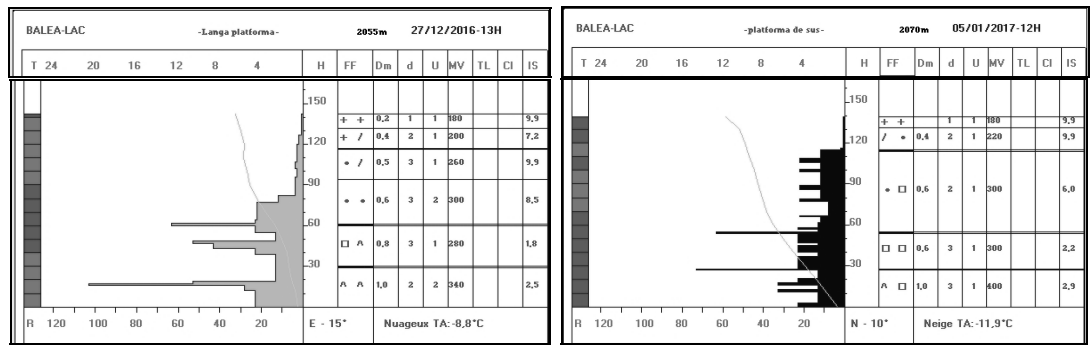

Fig. 4. Resistance, temperature and stratigraphic profiles from Bâlea-Lac, December 27, 2016 and January 05, 2017

On $3^{\text {rd }}$ January 2018 , the weather became fine and the temperatures rised up to a maximum of -0.9 degrees (at Bâlea-Lac). Rapid temperatures increase is an aggravating factor for avalanche triggering, that's why the estimated avalanche risk still remained high (4) - (Fig.5).

\subsection{Meteorological and snow conditions from 7 to 16 January 2017}

High avalanche risk (4) was estimated only for altitudes above 1,800 meters, both in Bucegi and Făgăraş massifs between 7 and 14 January and only in Făgăraş for 15 and 16 January. The weather was frosty during January 6 and 10 , with maximum temperatures at Bâlea-Lac between -20.0 and $-12,4$ degrees and minimum between $-25,2$ and $-15,3$ degrees (fig.5).
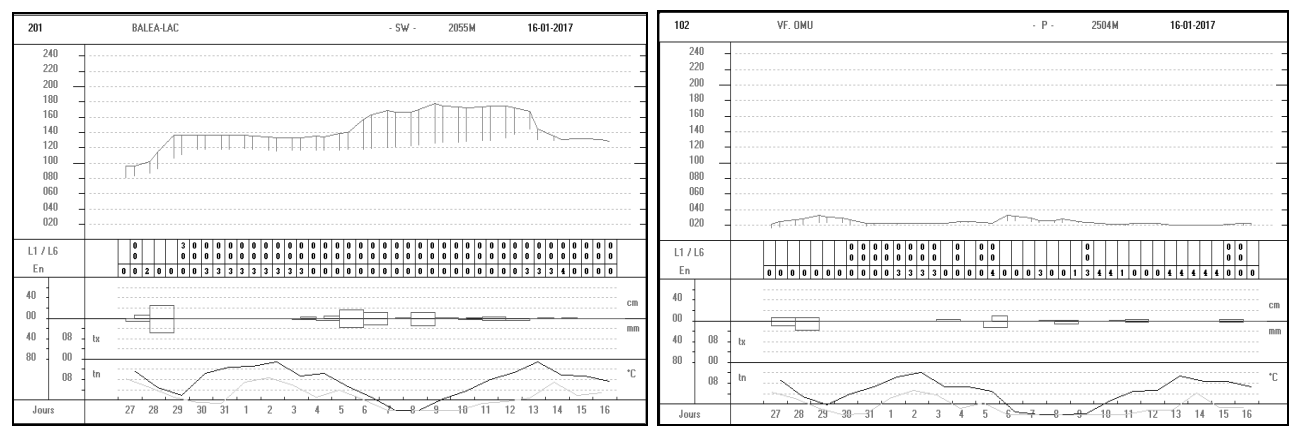

Fig. 5. Snow height, fresh snow, air temperature, wind speed at Bâlea-Lac and Vârfu Omu, during December 27, 2016 and January 16, 2017

Meanwhile, at Vârfu Omu meteorological station, fresh snow was not so high, but temperatures went down up to $-29,2$ degrees (8/9 january). Minimum temperatures were lower than -20 degrees from 5/6 to 13/14 january and remained lower than -15 degrees to the end of the studied period, except for the 13/14 january night, when raised to $-11,7$ degrees. As of maximum temperatures, they have been also very low, from $-21,7$ degrees (january 7) to $-5,2$ degrees (january 13) - (Fig.5). 
It snowed throughout all the mountainous area and up to $10 \ldots 20 \mathrm{~cm}$ of fresh snow have been deposited. Wind intensification also caused important snow accumulations. New fallen snow was very light, powder like, without cohesion between particles and has formed important deposites, especially in the valleys, due to the wind, that blowed it down.
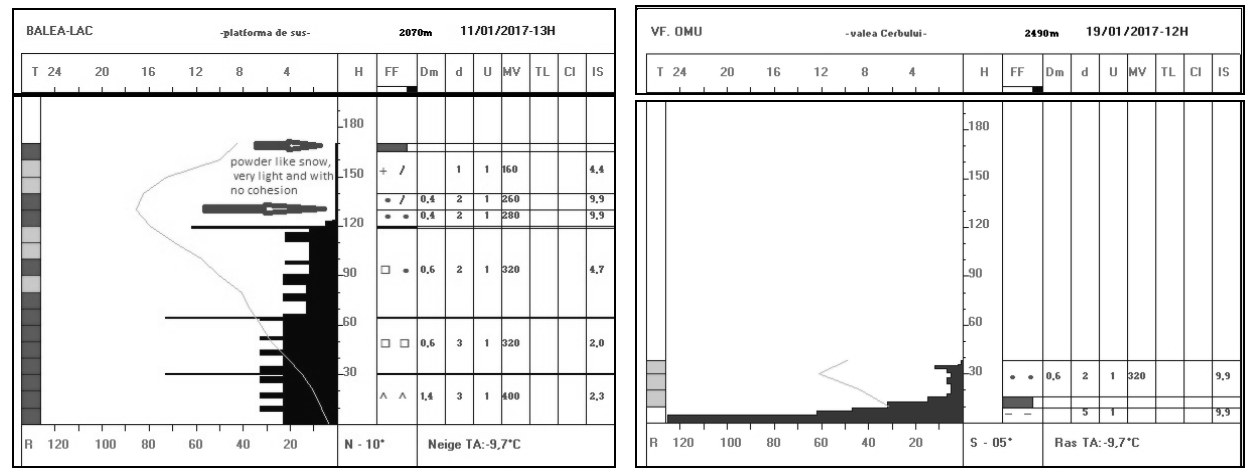

Fig. 6. Resistance, temperature and stratigraphic profiles: Bâlea-Lac (January 11, 2017) and Vârfu Omu - Cerbului Valley (January 19, 2017)

That weak layer was deposited over older ice crusts and oldest compact, stable snow layer underneath (Fig.6). Very low temperatures measured during that period slowed down the metamorphosis process of snow crystals, maintaining the powdered snow structure for several days. Because of this light snow, stability of the top snow layer remained very poor for several days and the possibilty of spontaneously large avalanches was high (risk 4). From $15^{\text {th }}$ January, over $1800 \mathrm{~m}$ altitude, high avalanche risk was estimated only for Făgăraş Mountains. Under the hardened part of the surface, the snow remained still soft and less resistant. The risk of avalanches triggering was mainly due to the possibility of breaking the slabs formed on the slopes, even at low overloads (Fig.6).

Meanwhile, in Bucegi Mountains, the estimated avalanche risk was considerable (3); here, snow in the crest areas was blowed away by the wind and accumulated in valleys and sheltered areas where has formed significant deposits. On the slopes slabs has been formed, which could be broken when overloading, leading to avalanches triggering, especially on inclined slopes (Fig.6).

\subsection{Meteorological and snow conditions from March 21 to 24, 2017}

During march 18 and 19, there have been important snowfalls in the high area of the Făgăraş Mountains. Fallen amounts were high, over $301 / \mathrm{mp}$ and a new layer of $38 \mathrm{~cm}$ of snow was deposited (at Bâlea-Lac). The wind blew over 60-70 $\mathrm{km} / \mathrm{h}$, depositing snow on valleys and sheltered areas and forming wind slabs on the slopes (Fig.7). Next days, the weather was warm and the sky was variable, temporarily cloudy. The wind blew moderately hard, with temporary intensities exceeding $60 \mathrm{~km} / \mathrm{h}$. Larger snow deposits on the valleys, and wind slabs were formed on the slopes. 
The $65 \mathrm{~cm}$ of recent snow from surface, accumulated over past days, was not stable. Inside the layer, snow was more compact and relatively stabilized, formed by faceted crystals, interspersed with ice crusts and a layer of about $30 \mathrm{~cm}$ cup-shaped crystals to the ground (Fig.7).
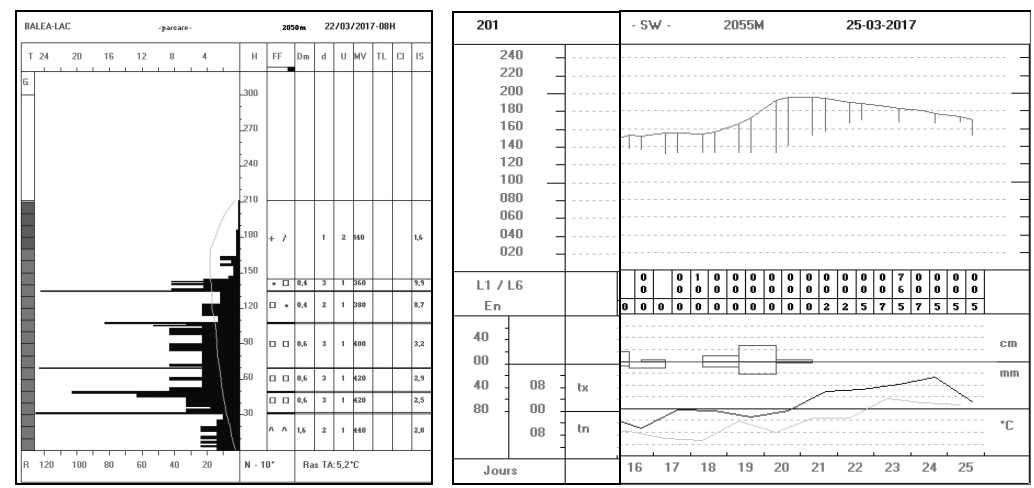

Fig.7. Bâlea-Lac: resistance, temperature and stratigraphic profiles, March22, 2017; Snow height, fresh snow, air temperature, wind speed, during March 16 to 25, 2017

High temperatures and sunstroke could thus easily cause snow melting and moisturing of the top snow, slipping of that moistured layer and breaking of the wind slabs and thus spontaneously avalanches could be triggered on numerous inclined slopes, the risk being amplified even under the conditions of a slight overload. Several avalanches and surface melting happened during that days on different slope direction and inclinations.

\subsection{Meteorological and snow conditions from April 09 to 11, 2017}

First snowfall began on April 6, on a rather warm day, with maximum termperature of $+0,8$ degrees and $13 \mathrm{~cm}$ of fresh snow until next morning. Temperature dropped on April 7 (maximum of -6.4 degrees), snow continued to fall, up to $27 \mathrm{~cm}$ fresh snow on April 08 morning. The weather remained cold, with cloudy sky and snowfall with significant quantities recorded in Făgăraş Mountains (22 $\mathrm{cm}$ of fresh snow at Bâlea-Lac). The wind blew moderately, with sustained intensities over $70 \mathrm{~km} / \mathrm{h}$ from north-north-east, depositing the snow in valleys and sheltered areas. The new snow layer, of about $40 \mathrm{~cm}$, was poor stabilized and with a low cohesion with the old layer (Fig.8).

During the next three days, the weather was beautiful and warm, with a most clear sky and isolated wind intensities on the ridges. Due to warm weather and sunstroke, fresh snow melted and moistened the top part. This latter layer acted as an overload, which could easily slip spontaneously over the former and harder snow layers, triggering melting avalanches of medium or even large size. Avalanche risk was estimated as high (4) in the high areas of Făgăraş Mountains, where melting avalanches were observed these days on several slopes. 

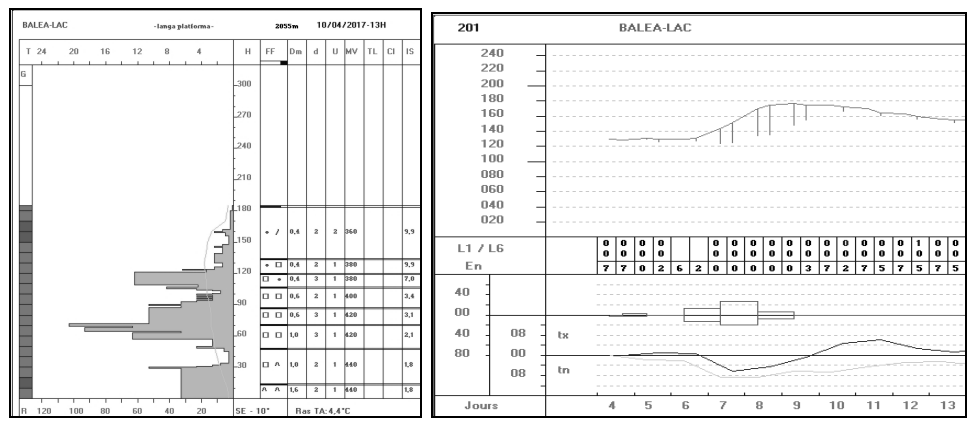

Fig.8. Bâlea-Lac: resistance, temperature and stratigraphic profiles, April 10, 2017;

Snow height, fresh snow, air temperature, wind speed, during April 04 to 13, 2017

\subsection{Meteorological and snow conditions from April 21 to 29, 2017}

On April 20 to 22, the weather was cold, with cloudy sky and snowfalls in all mountain areas. The quantities of new fallen snow locally exceeded $40 \mathrm{~cm}$ in 24 hours. During these three days, a total amount of $58 \mathrm{~cm}$ snow was acumulated at Bâlea-Lac, on Făgăraş Mountains. The wind blowed moderately, with temporary intensities over $80 \mathrm{~km} / \mathrm{h}$ on the ridges, blowing the snow on the valleys and sheltered areas and creating wind slabs on the exposed slopes. Local fog was also reported. Air temperatures values were from $-8,9$ to $-0,2$ degrees by day and $-12,3$ to $-10,6$ degrees by night (Fig.9).
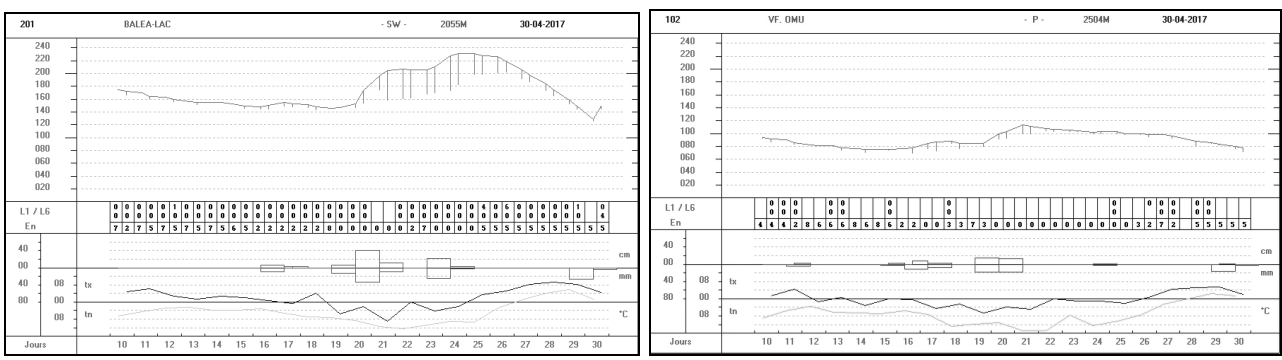

Fig.9. Snow height, fresh snow, air temperature, wind speed at Bâlea-Lac and Vârfu Omu, between April 10 and 30, 2017

Fresh snow was poor stabilized and avalanche triggering possible even at a slight overload on many inclined slopes, but spontaneous avalanches of medium and even large avalanches were also expected. Thus, beginning with April 22, a very high avalanche risk was estimated.

Weather remained relatively cold until April 25, when temperatures became positive, even by night. Avalanche risk remained high over 1800 meters, and triggering was possible both spontaneously, on many slopes, due to rising temperatures and sunstroke, as well as on weak overloads (Fig.10). Until April 29, warm weather and sunshine will still cause the top layer of snow to wet. Sliding of the relatively recent and wet top layer over the older layers would be likely under a 
slight overload, especially on sloping slopes, by breaking the slabs. Spontaneously, however, meltdowns and avalanches have occured every warm day.
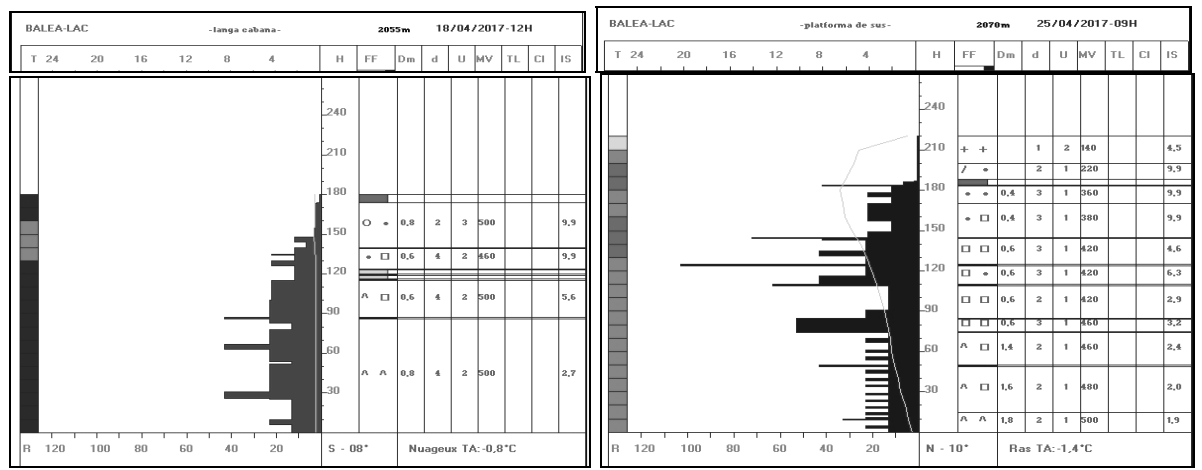

Fig.10. Resistance, temperature and stratigraphic profiles, Bâlea-Lac: April 18, 25, 2017

\section{CONCLUSIONS}

The presented cases show that avalanches have occured during the 2016 2017 winter season mainly under the direct influence of heavy snowfall or increasing temperatures, and very few on snow crystals transformations within the layer, especially on the formation of faceted, unstable crystals inside.

The annual studies based on the observations and measurements from the four meteorological stations with a nivological program are part of a complex study aiming the elaboration of a climatology of the conditions in which the avalanches in the Carpathians are triggered and the shaping of their patterns (Mair and Nairz, 2010).

In order to avoid any human life loss, but also to prevent massive accidents with significant economic damage, permanent snow and avalanche measurements are needed, especially in areas with high tourist potential.

\section{REFERENCES}

1. Casterbrunet, H. et al (2012), Snow and weather climatic control on snow avalanche occurrence fluctuations over 50yr in the French Alps, Clim. Past, 8, 855-875.

2. Greene, E., Wiesinger, T., Birkeland, K., Coléou, C., Jones, A., Statham, G. (2006), Fatal avalanche accidents and forecasted danger levels: Patterns in the United States, Canada, Switzerland and France, ISSW.

3. Jaedicke, C., Bakkehøi, S. (2007), Climate database for avalanche consulting and warning in Norway, Cold Regions Science and Technology, 47, 1-2, 171-179.

4. McClung, D., Schaerer, P. (1993), The Avalanche Handbook

5. Rudi, M., Nairz, P. (2010), Lawine. Die 10 entscheidenden Gefahrenmuster erkennen: Praxis-Handbuch, Verlagsanastalt Tyrolia, Innsbruck.

6. ***, Bilanţul nivologic al sezonului de iarnă - publicație anuală, începând din 2004, Administraţia Naţională de Meteorologie, Bucureşti.

7. ***, Buletinul nivometeorologic - arhiva, Serviciul Regional de Prognoză a Vremii Sibiu.

8. http://www.avalanches.org accesed on December 28, 2016 and January 4, 2017. 